\title{
Sub-Optimal Degree Distribution untuk Prioritas Komunikasi Manusia menggunakan Proyeksi EXIT Chart pada Jaringan Masa Depan
}

\author{
SOLICHAH LARASATI, KHOIRUN NI'AMAH
}

Program Studi S1 Teknik Telekomunikasi Institut Teknologi Telkom Purwokerto

Email: laras@ittelkom-pwt.ac.id

Received 15 Maret 2019 | Revised 23 Mei 2019 | Accepted 11 Juli 2019

\begin{abstract}
ABSTRAK
Pada jaringan masa depan melibatkan komunikasi antara mesin dan manusia. Penelitian ini mengusulkan konsep coding dalam jaringan menggunakan Maximum Distance Separable (MDS) codes. Desain sub-optimal degree distribution untuk memprioritaskan manusia menggunakan proyeksi EXIT Chart. Pada penelitian ini dasar dari skema multiple akses untuk jaringan super-padat menggunakan Coded Random Access (CRA). Usulan model jaringan menggunakan Binary Erasure Channel (BEC). Evaluasi performansi untuk grup manusia dan mesin diukur berdasarkan throughput dan packet-loss-rate dan hasilnya juga dibuktikan menggunakan frequency-flat Rayleigh fading. Sub-optimal degree distribusi yang diusulkan untuk manusia $((8,2), 1)$ dan untuk mesin $((3.2), 0.2),((4,2), 0.8))$, dengan hasil throughput sebelum fading untuk manusia 0.35 paket/slot dan throughput mesin 0.32 paket/slot, sedangkan setelah fading throughput manusia 0.34 paket/slot dan throughput mesin 0.22 paket/slot.
\end{abstract}

Kata kunci: MDS codes, CRA, human, machines, EXIT chart

\begin{abstract}
Future wireless network involving machines and human communications. This research proposed new concept of network coding based on Maximum Distance Separable (MDS) codes. Designed optimally sub-optimal degree distribution for prioritizing human using projected EXIT chart. This research fundamental multiple access scheme for wireless super-dense network using Coded Random Access (CRA). In this research, proposed scheme under Binary Erasure Channel (BEC) to model a network. We evaluate the performance for human and machines group in terms of throughput and packet-loss-rate, and the result are then verified using frequency-flat Rayleigh fading. We have proposed sub-optimal degree distributions for human $((8,2), 1)$ and for machines $((3.2), 0.2),((4,2), 0.8))$, the resulting throughput for human 0.35 packet/slot and throughput for machines 0.32 packet/slot under fading and without fading throughput for human 0.34 packet/slot than throughput for machines 0.22 packet/slot.
\end{abstract}

Keywords: MDS codes, CRA, human, machines, EXIT chart 
Sub-Optimal Degree Distribution untuk Memprioritaskan Manusia menggunakan Proyeksi EXIT Chart pada Jaringan Masa Depan

\section{PENDAHULUAN}

Perkembangan teknologi wireless mengalami kenaikan pada tahun 2020, yaitu pada generasi kelima (5G). Generasi telekomunikasi 5G melibatkan komunikasi yang sangat besar (massive) dimana jumlah mesin/device yang terkoneksi ke internet mencapai 50 miliar padahal jumlah penduduk dunia sekitar 5 milyar, sehingga jika kondisi tersebut benar terjadi jumlah manusia hanya $1 / 10$ bagian dalam jaringan tersebut (Ericsson, 2011). Kondisi ini memerlukan sebuah teknik multiple access yang mampu mendukung jumlah user yang sangat banyak pada jaringan masa depan. Gambar 1 merupakan gambaran struktur jaringan super padat masa depan untuk komunikasi uplink dari jumlah $M$ user. Total user $U=\left(U_{1}, U_{2}, \ldots, U_{M}\right)$ adalah gabungan dari manusia dan mesin dimana pengiriman paket melalui Base Station (BS) yang terkoneksi dengan internet.

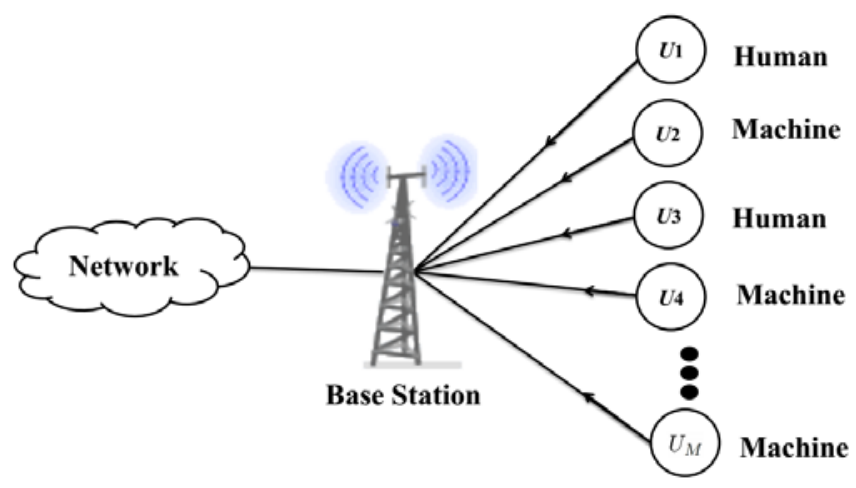

Gambar 1. Jaringan Super Padat dengan Jumlah $M$ user.

Teknik multiple access yang mampu memenuhi kondisi tersebut yaitu Coded Random Access (CRA) (Hasan \& Anwar, 2015) (Hasan \& Anwar, 2015). Skema CRA menjadi solusi yang baik untuk masalah multiple access pada jaringan super padat masa depan, karena teknologi sebelumnya seperti Time Division Multiple Access (TDMA), Frequency Division Multiple Access (FDMA), dan Coded Division Multiple Access (CDMA) tidak menjamin untuk akses user yang besar dengan batasan time slot. CRA mempunyai dua kunci utama yaitu coding dan random. Coding digunakan untuk memproteksi paket dari error dan diselesaikan menggunakan degree distribution, sedangkan random memberikan fleksibilitas user untuk memilih time-slot dengan bantuan Succesive Interference Cancellation (SIC).

(Toni \& Frossard, 2015) mengusulkan teknik transmisi menggunakan skema Irregular Repetition Slotted ALOHA (IRSA), dimana sumber informasi yang dikirimkan oleh Base Station (BS) dengan strategi IRSA. Prioritas kelas pada referensi ini diidentifikasi menggunakan utility function, dikelompokkan berdasarkan kelas bukan berdasarkan manusia atau mesin. (Woo \& Cheng, 2008) mengusulkan skema modifikasi konvensional LT Codes untuk degree distribution untuk high priority data dan lower priority data. (Purwita \& Anwar, 2016) mengusulkan massive multiway relaymemakai CRA untuk memilih topologi yang fleksibel agar mampu mencakup jumlah useryang banyak.

Pada jurnal ini, penulis mengusulkan sebuah skema coding untuk memprioritaskan komunikasi manusia dibandingkan komunikasi mesin menggunakan Maximum Distance Separable (MDS) codes, dimana pembagian komunikasi manusia dan mesin berdasarkan degree distribution. Skema coding membantu dalam desain degree distribution tiap grup, sehingga komunikasi tetap reliable dan komunikasi manusia tidak kalah dengan komunikasi mesin walaupun 
bercampurnya seluruh data dalam jaringan pada masa depan. Komunikasi manusia lebih diutamakan daripada mesin karena biasanya komunikasi manusia merupakan komunikasi yang urgent/mendesak, contohnya komunikasi petugas ambulans dengan dokter di rumah sakit tidak boleh lebih buruk daripada komunikasi antar sensor, sebab jika komunikasi petugas ambulan dengan dokter tersebut dikalahkan dengan komunikasi sensor, maka akan membahayakan nyawa pasien. Kontribusi dari penelitian ini menjawab tantangan jaringan heterogen di masa depan, saat beragam komunikasi yang memiliki bit rate berbeda, aplikasi berbeda, delay, dan sebagainya, tetapi semua bercampur dalam satu jaringan. Sasaran dari penelitian ini adalah sebuah usulan untuk mendukung manusia dan lebih mengutamakan manusia dengan cara mendesain sub-optimal degree distribution dan utility function untuk grup manusia dan mesin menggunakan rojected Extrinsic Information Transfer (EXIT) chart, dimana grup manusia diharapkan harus lebih tahan error dibandingkan grup mesin, sehingga komunikasi tetap reliable dan loss rate dapat diminimalkan, parameter evaluasi adalah throughput dan Packet-Loss-Rate (PLR).

Penulisan ini dibagi menjadi beberapa bagian. Bab 2 mendeskripsikan sistem model dari CRA untuk memprioritaskan manusia. Bab 3 berisi usulan dari desain prioritas CRA dengan kode MDS untuk masing-masing grup menggunakan Proyeksi EXIT Chart. Bab 4 performa dari desain degree disribution yang dilihat dari parameter throughput, PLR, serta pengaruh frequency-flat Rayleigh Fading. Bab 5 berisi kesimpulan dari hasil yang diperoleh.

\section{METODE PENELITIAN}

Struktur transmisi yang penulis usulkan dapat dilihat pada Gambar 2. Gambar 2 menggambarkan bipartite-graph dari CRA, dimana manusia diberikan kebebasan untuk mengakses semua time-slot (TS) secara acak, sedangkan mesin diberikan batasan untuk mengakses TS. Total user ( $n$ ) adalah jumlah total dari user manusia dan mesin $(M h+M m)$, manusia $\left(U^{h}=U_{1}^{h}, \ldots, U_{M h}^{h}\right)$ dan mesin $\left(U^{m}=U_{1}^{m}, \ldots, U_{M m}^{m}\right)$, total time $\operatorname{slot}\left(N=T_{1}, \ldots, T_{N}\right)$.

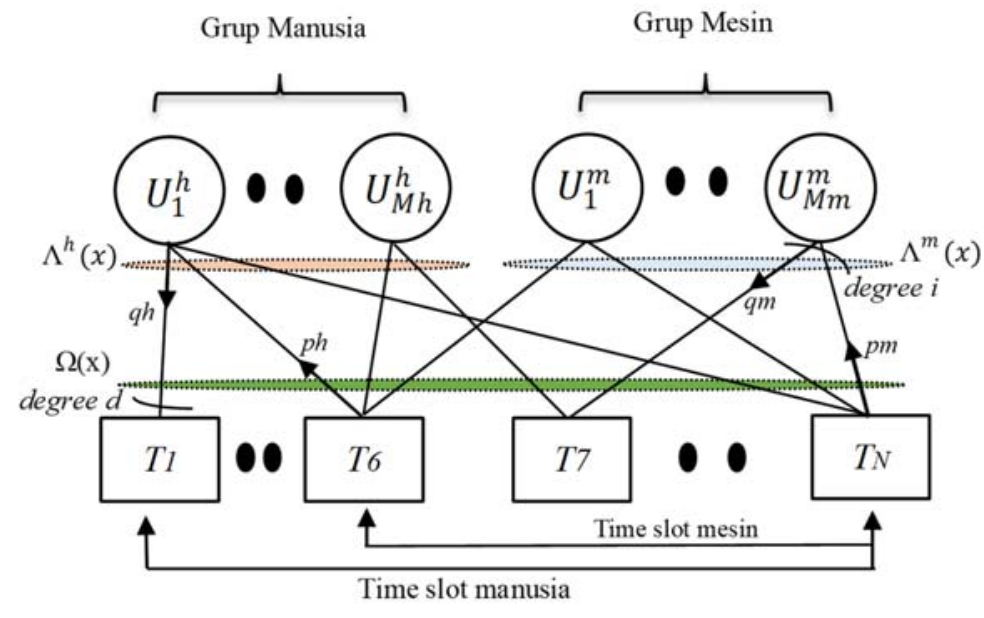

\section{Gambar 2. Bipartite-Graph CRA untuk Komunikasi Manusia dan Mesin}

Tujuan dari penulisan ini adalah untuk menghasilkan strategi transmisi yang baik untuk memaksimalkan jumlah user masing - masing grup dengan TS yang terbatas serta menentukan sub-optimal degree distribution untuk memprioritaskan manusia, dimana manusia diberikan kebebasan untuk dapat mengakses semua TS. Oleh karena itu, prediksi kesuksesan manusia harus lebih besar daripada mesin. Salah satu strategi transmisi yang diharapkan untuk 
memaksimalkan komunikasi tersebut menggunakan utility function pada semua grup. Secara praktiknya, utility function dapat diatur berdasarkan jumlah populasi dalam suatu kota. Beda kota berbeda juga utility function-nya, misalnya kota A. Kota A memiliki populasi manusia 2.490.622 dan asumsi jumlah mesin/devices 17.434.354, sehingga kita dapat mengatur utility function-nya $f_{u}\left(M_{h}, M_{m}\right)=(30: 70)$.

Degree distribution merupakan distribusi banyaknya transmisi dari user dan untuk menjamin proses berlangsungnya transmisi tersebut menggunakan bantuan SIC. SIC adalah sebuah konsep management interferensi, dalam SIC terjadi cancel interferensi yang berkelanjutan sampai mendapatkan degree 1. Proses SIC berada pada receiver dan ditempatkan di Base Station (BS). Jurnal ini mengasumsikan masing-masing paket menggunakan Binary Erasure Channel (BEC). Terdapat dua tipe skema encoding yaitu physical encoding dan network encoding. Penulis mengasumsikan physical encoding perfect sebagai contoh pada simple convolutional codes (Anwar \& Matsumoto, 2012) dan irregular low density parity check (LDPC) (Chung, Forney, Jr, Richardson, \& Urbanke, 2011).

Proses optimisasi dari network encoding dengan maximum offered traffic. Nilai offered traffic dapat dihitung menggunakan Persamaan (1).

Dimana

$$
G=G_{h}+G_{m}
$$

$$
G_{h}=\frac{M_{h}}{N_{m}}, G_{m}=\frac{M_{m}}{N_{m}}
$$

Offered traffic untuk manusia dan mesin dinotasikan $G_{h}$ dan $G_{m}$. Oleh karena itu, rata-rata rate untuk manusia dan mesin dalam jaringan dapat dihitung dengan Persamaan (3) dan (4):

$$
\begin{aligned}
& R_{h}=\frac{\overline{k^{h}}}{\overline{n^{h}}}=\frac{\sum_{i}^{H_{k}^{h}} \Lambda_{i}^{h} k_{i}}{\sum_{i}^{H_{n}^{h}} \Lambda_{i}^{h} n_{i}} \\
& R_{m}=\frac{\overline{k^{m}}}{\overline{n^{m}}}=\frac{\sum_{i}^{H_{k}^{m}} \Lambda_{i}^{m} k_{i}}{\sum_{i}^{H_{n}^{m}} \Lambda_{i}^{m} n_{i}}
\end{aligned}
$$

Dimana $R_{h}$ dan $R_{m}$ adalah rata-rata rate untuk manusia dan mesin, $H_{k}^{h}$ dan $H_{k}^{m}$ adalah jumlah maksimal dari $k$ dan $n$ untuk manusia. $H_{k}^{m}$ dan $H_{n}^{m}$ adalah jumlah maksimal dari $k$ dan $n$ untuk mesin. Parameter $k$ adalah parameter dari skema network encoding, dimana $k>1$ untuk MDS codes. Sebuah kode $c_{i}\left(n_{i} k_{i}\right)$ adalah kode yang linear dengan panjang kode $n_{i}$ dan dimensi $k_{i}$.

Efek fading dalam sebuah jaringan di antara base station dan mobile station terjadi karena terdapat karakteristik obstacle dan reflection. Penurunan offered traffic pada saat fading terjadi karena fenomena fluktuasi sinyal akibat adanya multipath fading. Multipath fading mengakibatkan error rate pada data yang diterima ketika sinyal ditransmisikan. Sebuah metode kompensasi dari multipath fading harus digunakan untuk memastikan transmisi memiliki performansi yang tinggi. Penelitian ini diasumsikan menggunakan transmisi narrowband, sehingga asumsi frequency-flat Rayleigh fading yang cocok digunakan.

Probabilitas density function dari frequency-flat Rayleigh fading channel pada single path dilihat pada Persamaan (5): 


$$
p(r)=\frac{r}{\sigma^{2}} \cdot \exp \left(\frac{-r^{2}}{2 \sigma^{2}}\right)
$$

Untuk sinyal penerima $r$ dapat dilihat pada Persamaan 6:

$$
r=h . s+n
$$

\section{USULAN CODED RANDOM ACCESS(CRA) DENGAN PRIORITAS}

Bab ini mengusulkan skema prioritas menggunakan sub-optimal degree distribusi yaitu tidak lebih dari dua fraction. Bipartite Graph CRA yang diusulkan seperti pada Gambar 2 menggambarkan user node (UN) dengan degree i dan slot node (SN) dengan degree $d$. Catatan bahwa yang dapat didesain hanya degree $i$, sedangkan degree $d$ tidak dapat didesain karena kondisi alam yang menentukan.

\subsection{Degree Distribution Masing-masing Node}

Usulan prioritas untuk jaringan super padat ditentukan dengan dua utility function yaitu:

1. Utility function untuk user $f_{u}\left(M_{h}, M_{m}\right)=(0.3: 0.7)$, dimana dalam satu jaringan manusia $30 \%$ dan mesin $70 \%$.

2. Utility function untuk time-slot $f_{s}\left(N_{h}, N_{m}\right)=(1: 0.9)$, dimana dalam satu jaringan manusia dapat mengakses $100 \%$ dari time-slot yang digunakan tetapi mesin dibatasi hanya dapat mengakses $90 \%$ saja dari total time-slot yang digunakan. Target dari konsep prioritas ini adalah memaksimalkan jumlah dari total user $M=M_{h}+M_{m}$ dalam satu time-slot $(N)$ yang sama. Skema prioritas dilakukan dengan membatasi time-slot yang akan digunakan untuk mesin, sehingga $N_{h}<N_{m}$ dan $N_{h}=N$.

Dalam praktiknya, utility function dapat digunakan sebagai parameter untuk mengukur populasi suatu kota. Beda kota maka beda pula utility function yang digunakan (Larasati, Ramatryana, \& Anwar, 2018). Desain yang dilakukan menggunakan practical parameter yaitu jumlah $N=200$ slot, kita tidak dapat mengatur time-slot terlalu besar atas dasar pertimbangan dari low network latency (Anwar, 2016). Kenaikan dari $N=200$ tidak memiliki efek yang signifikan terhadap error floor (Anwar, 2016) dan sudah support untuk diimplementasikan secara praktikal. Sebelum melakukan desain menggunakan practical parameter, langkah awal adalah melakukan analisis asymptotic untuk grup manusia dan grup mesin dalam jaringan. Ketika jumlah manusia sangat besar $\left(M_{h} \rightarrow \infty\right)$, maka perlu dijaga supaya traffic $G_{h}=\frac{M_{h}}{N_{h}}$ bernilai konstan, hal tersebut berlaku sama juga untuk grup mesin. Seperti pada bipartite graph untuk mendesain degree distribution manusia dan mesin menggunakan persamaan polynomial. Terdapat dua tahap yaitu menggunakan node perspective degree distribution dan edge perspective degree distribution. Persamaan untuk mendesain node perspective degree distribution untuk UN manusia seperti yang ditunjukkan pada Persamaan (7) (Larasati, Ramatryana, \& Anwar, 2018).

$$
\Lambda^{h}(x)=\sum_{i=2}^{H_{k}^{h}} \Lambda_{i}^{h} x^{i}
$$


Sedangkan node perspective degree distribution untuk UN-mesin adalah $\Lambda^{m}(x)$. Egde perspective degree distribution untuk UN-manusia dan UN-mesin masing-masing ditunjukkan pada Persamaan (8) dan (9) (Larasati, Ramatryana, \& Anwar, 2018).

$$
\begin{aligned}
& \lambda^{h}(x)=\frac{1}{\Lambda^{\prime}(1)} \sum_{i=2}^{H_{k}^{h}} \mathrm{i} \Lambda_{i}^{h} \gamma_{i}(x) \\
& \lambda^{m}(x)=\frac{1}{\Lambda^{\prime}(1)} \sum_{i=2}^{H_{k}^{m}} \mathrm{i} \Lambda_{i}^{m} \gamma_{i}(x)
\end{aligned}
$$

dimana $\Lambda_{i}^{h}$ dan $\Lambda_{i}^{m}$ adalah probabilitas dari UN-manusia dan UN-mesin yang memiliki degree $i$, sedangkan $H_{k}^{h}$ adalah degree maksimal dari UN manusia dan $H_{k}^{m}$ adalah degree maksimal dari degree UN-mesin. Parameter dari kode MDS yang dinotasikan $\gamma_{i}(x)$ akan dibahas pada bab selanjutnya.

Supaya lebih sederhana dalam melakukan analisis, maka diasumsikan perbedaan dalam $f_{s}\left(N_{h}, N_{m}\right)$ adalah $\left(N_{h}, N_{m}\right) \rightarrow 0$. Persamaan (10) merupakan persamaan untuk memperoleh probabilitas SN yang memiliki degree d (Larasati, Ramatryana, \& Anwar, 2018).

$$
\Omega_{d}=\left(\begin{array}{c}
M_{h} \\
d_{h}
\end{array}\right)\left(\begin{array}{c}
M_{m} \\
d_{m}
\end{array}\right)\left(\frac{G_{h}}{\overline{\overline{R_{h}}} M_{h}}\right)^{d}\left(\frac{G_{m}}{\overline{\overline{R_{m}}} M_{m}}\right)^{d}\left(1-\frac{G_{h}}{\overline{\overline{R_{h}} M_{h}}}\right)^{M_{h} d_{h}}
$$

dimana $d=d_{h}+d_{m}$. Polinomial untuk degree distribusi SN dilihat pada Persamaan (9).

$$
\begin{aligned}
\Omega(x) & =\sum_{d=0}^{M} \Omega_{d}^{h} x^{d}, \\
& =\left(1-\frac{G_{h}}{\overline{\overline{R_{h}}} M_{h}}\left(1-x_{h}\right)^{M_{h}} \cdot\left(1-\frac{G_{m}}{\overline{\overline{R_{m}} M_{m}}}\left(1-x_{m}\right)^{M_{m}}\right.\right.
\end{aligned}
$$

Jika $M \rightarrow \infty$ dan $N \rightarrow \infty$, maka Persamaan (12) menjadi:

$$
\begin{aligned}
\omega(x) & =\lim _{M \rightarrow \infty}\left(1-\frac{G_{h}}{\overline{R_{h} M_{h}}}\left(1-x_{h}\right)^{M_{h}} \cdot\left(1-\frac{G_{m}}{\overline{R_{m}} M_{m}}\left(1-x_{m}\right)^{M_{m}},\right.\right. \\
& \approx \exp \left\{\left(-\frac{G_{m}}{R_{m}}+\frac{G_{h}}{R_{h}}\right)+\frac{G_{m}}{R_{m}} x_{m}+\frac{G_{h}}{R_{h}} x_{h}\right\}
\end{aligned}
$$

dimana $x=x_{m}+x_{h}$.

\subsection{Maximum Distance Separable (MDS) Codes $\left(n_{i}, k\right)$}

MDS Codes merupakan salah satu kode yang harus memenuhi Singleton bound yaitu kode dengan jarak minimum adalah panjang kode dikurang dengan dimensi kode ditambah satu, atau seperti Persamaan (13).

$$
j \leq n_{i}-k_{i}+1
$$

Dimana $j$ adalah jarak minimal kode, $n_{i}$ adalah panjang kode, dan $k_{i}$ adalah dimensi kode. MDS merupakan salah satu kode yang istimewa dan menarik karena memiliki nilai $n_{i}$ dan $k_{i}$, 
sehingga memiliki error deteksi dan error koreksi yang lebih baik. MDS codes memiliki rate > $1 / 2$ dengan notasi $\left(n_{i}, k_{i}\right)$, hal ini berbeda dengan repetition codes yang memiliki rate $\leq$ $1 / 2$ dengan notasi $\left(n_{i}, 1\right)$.

\subsection{Analisis Proyeksi EXIT Chart}

Extrinsic Information Transform (EXIT) Chart merupakan sebuah proses pertukaran informasi dan dapat digunakan sebagai analisis proses iterasi decoder. Untuk mendapatkan EXIT Chart diperlukan mutual information yang merepresentasikan kandungan informasi apabila output kanal sudah diketahui. Nilai pertukaran informasi yang ditukar adalah extrinsic mutual information dan apriori mutual information. Dalam jurnal ini usulan utama dari analisis EXIT chart untuk mendesain sub-optimal degree distribution dari grup manusia dan grup mesin agar diperoleh performansi yang optimal. Performansi terbaik dilihat dari gap terkecil antara UN dan SN. Pada jurnal ini menggunakan EXIT Chart Projection karena time slot dibagi menjadi dua grup (manusia dan mesin), sehingga time-slot dipengaruhi oleh dua kondisi. Mesin yang diproyeksinya terhadap time-slot dinamakan proyeksi SN-mesin, sedangkan grup manusia yang diproyeksikan terhadap time-slot dinamakan proyeksi SN-manusia.

Prosedur optimasi digunakan untuk memperoleh hasil yang efisien dengan kualitas yang baik. Adapun prosesur optimasi untuk memaksimalkan jumlah dari manusia dan mesin dengan timeslot yang terbatas adalah:

$$
\begin{array}{ll}
\text { Nilai offered traffic maksimal } & G=G_{h}+G_{m}, \\
\text { Parameter optimasi } & R_{h}<R_{m}, k_{i} \leq 3, n_{i} \leq 7, \\
& N \leq 200 \\
& f_{S N}>f_{U N}
\end{array}
$$

dimana $f_{S N}$ dan $f_{U N}$ adalah kurva EXIT function dari SN dan UN. Nilai EXIT function $f_{U N}$ bergantung dari degree distribution yang didesain sesuai dengan Persamaan (7). Berdasarkan persamaan tersebut maka sub-optimal degree distribution yang diperoleh adalah:

$$
\begin{aligned}
& \Lambda^{\mathrm{h}}(x)=\{((8,2), 1)\} \\
& \Lambda^{m}(x)=\{((3,2), 0.2),((4,2), 0.8)\}
\end{aligned}
$$

Usulan degree distribution $\Lambda^{h}(x)$ mempunyai rate 0.25 , sedangkan $\Lambda^{m}(x)$ mempunyai rate 0.53 .

Penelitian ini menggunakan model kanal Binary Erasure Channe/ (BEC), dimana probabilitas dari paket yang dihapus dalam jaringan direpresentasikan menggunakan erasure probability. Merujuk pada Gambar 2 contohnya, penulis fokus pada grup manusia terlebih dahulu, dimana $p_{h}$ merupakan erasure probability yang masuk ke UN-manusia, sedangkan $q_{h}$ merupakan erasure probability yang keluar dari UN-manusia.

Persamaan (16) adalah fungsi dari mutual information pada EXIT chart (Larasati, Ramatryana, \& Anwar, 2018).

$$
\begin{aligned}
& I_{A, U N}^{h}=1-p_{h} \\
& I_{E, U N}^{h}=1-q_{h \prime}
\end{aligned}
$$


Sub-Optimal Degree Distribution untuk Memprioritaskan Manusia menggunakan Proyeksi EXIT Chart pada Jaringan Masa Depan

Erasure probability yang keluar dari UN MDS Codes dilihat pada Persamaan (17).

dimana

$$
\begin{aligned}
q_{h} & =\lambda^{h}\left(p_{h}\right), \\
& =\sum_{i=2}^{H_{k}^{h}} \frac{i \Lambda_{i} \gamma_{i}(p)}{\Lambda^{\prime}(1)},
\end{aligned}
$$

$$
\gamma_{i}(p)=\sum_{l=0}^{k-1}\left(\begin{array}{c}
n_{i} \\
l
\end{array}\right)\left(1-p_{h}\right)\left(p_{h}\right)^{n_{i}-l-1}
$$

Erasure probability yang keluar dari SN dilihat pada Persamaan (19).

$$
\begin{aligned}
\left(1-p_{h}\right) & =\omega^{m}\left(1-q_{m}\right) \cdot \omega^{h}\left(1-q_{h}\right), \\
& =\exp \left\{-\left(\frac{G_{h}}{R_{h}}\left(1-q_{h}\right)-\frac{G_{m}}{R_{m}}\left(1-q_{m}\right)\right)\right\}
\end{aligned}
$$

Sama seperti grup manusia, nilai erasure probability juga diaplikasikan untuk grup mesin dengan hasil $q_{m}$ dan $p_{m}$, sehingga nantinya akan didapatkan $I_{E, U N}^{m}$ dan $I_{E, S N}^{m}$.

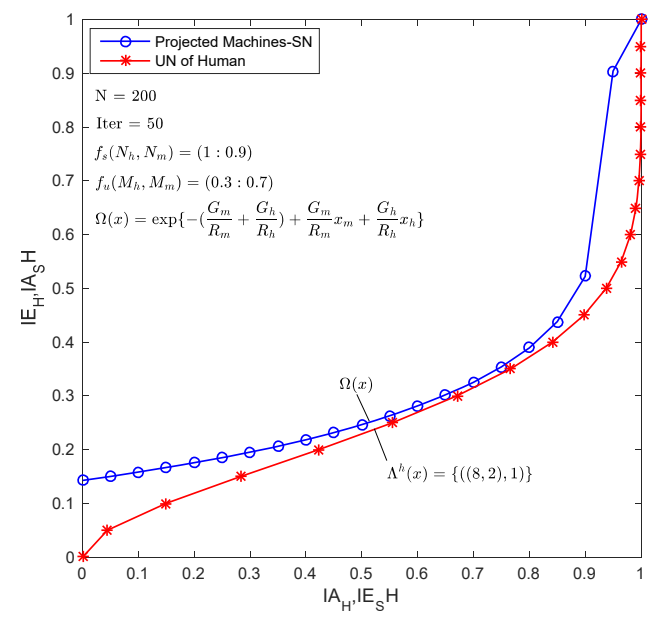

(a)

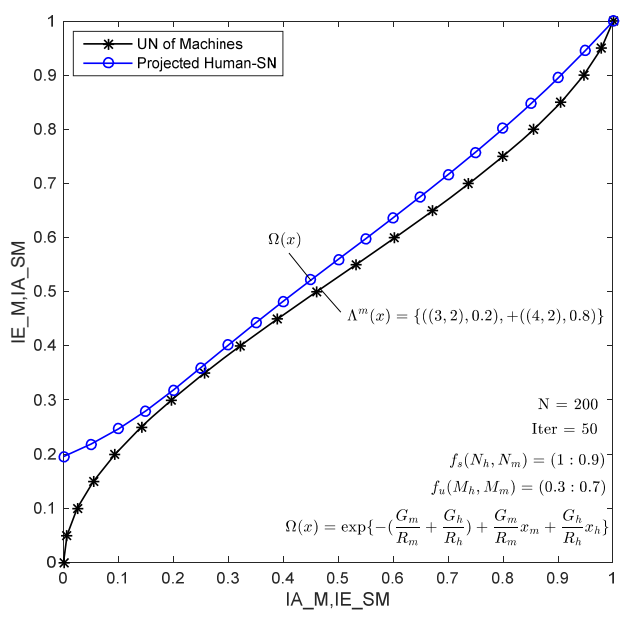

(b)

\section{Gambar 3. (a) Proyeksi EXIT Chart dari SN-Mesin terhadap UN-Manusia (b) Proyeksi EXIT Chart dari UN-Mesin terhadap SN-Manusia dengan $f_{s}\left(N_{h}, N_{m}\right)=(1: 0.9)$ dan $f_{u}\left(M_{h}, M_{m}\right)=(0.3: 0.7)$.}

Hasil grafik kurva EXIT pada Gambar 3 baik untuk grup manusia dan mesin dilakukan sebanyak 50 iterasi dan total jumlah time-slot-nya 200. Gambar 3 (a) merupakan proyeksi EXIT Chart antara SN-mesin dengan UN-manusia. Kurva dengan symbol "*" adalah degree distribusi manusia $\left(\Lambda^{\mathrm{h}}(x)\right)$, sedangkan kurva dengan simbol "o" adalah proyeksi SN-Mesin. Sama halnya seperti Gambar 3 (a), Gambar 3 (b) merupakan kurva EXIT yang menunjukkan proyeksi antara UN-mesin dengan SN-manusia. Kurva dengan simbol "*" adalah degree distribusi mesin $\left(\Lambda^{\mathrm{m}}(x)\right)$, sedangkan kurva dengan simbol "o" adalah proyeksi SN-manusia. Degree distribution yang diusulkan sudah cukup baik hal tersebut dapat dilihat dari pertemuan antara dua kurva 
EXIT memiliki gap (celah) yang kecil. Semakin kecil gap, maka kurva EXIT semakin bagus karena loss rate semakin kecil.

\subsection{Algoritma Decoding}

Gambar 4 merupakan skema algoritma dalam tahapan proses decoding dari MDS Codes, sebagai contoh MDSyang memiliki kode $(4,2)$ untuk grup manusia dan $(3,2)$ untuk grup mesin. Adapun langkah-langkah yang digunakan sebagai berikut:

a. Langkah 1: User yang terbagi menjadi dua grup yaitu manusia dan mesin terkoneksi dengan time-slot yang memiliki degree d. Proses decoding terjadi apabila user yang terkoneksi dengan time-slot memiliki $\mathrm{d}=1$. MDS codes memiliki $\left(n_{i}, k_{i}\right)$, maka proses decoding terjadi apabila useryang memiliki $\mathrm{d}=1$ sebanyak $k_{i}$ yang digunakan, seperti yang diilustrasikan pada Gambar 4 (a). Pada Gambar 4 (a) manusia memiliki nilai $k_{i}$ sebanyak 2, maka manusia dapat terdeteksi apabila jumlah degree $\mathrm{d}=1$ sebanyak 2 (berada TS 3 dan TS 5).

b. Langkah 2: Proses akan terus berlanjut untuk semua user (manusia dan mesin), sehingga semua dapat terdeteksi. Apabila tidak ada lagi user yang memiliki degree 1, maka proses decoding akan berhenti.

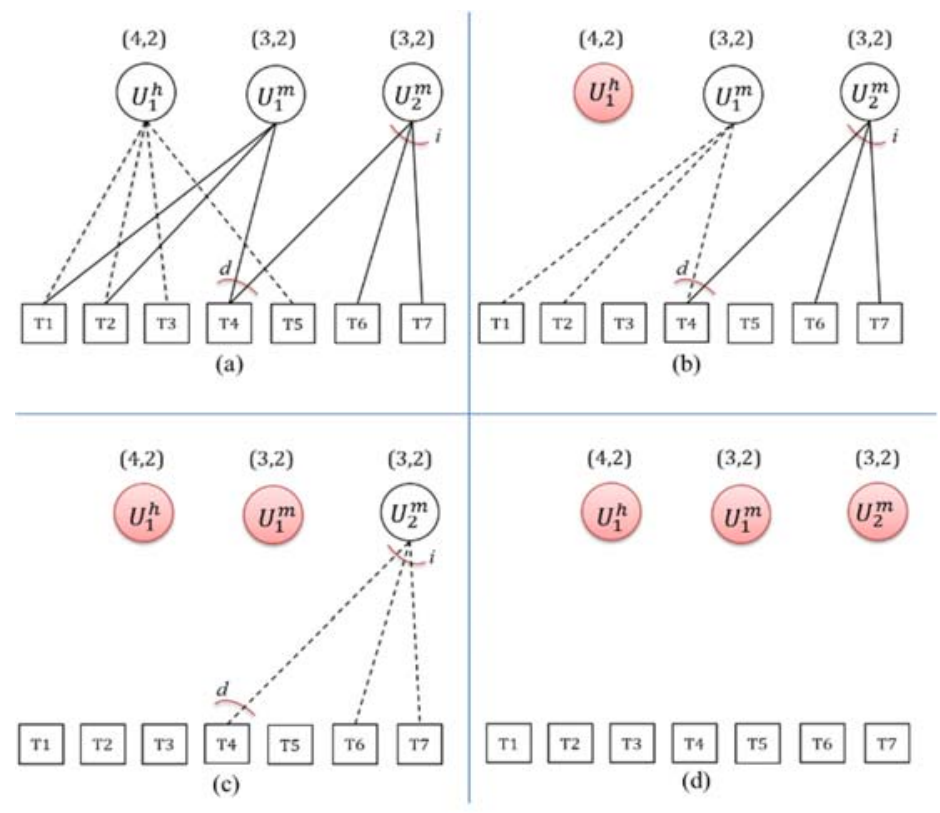

Gambar 4. Skema Algoritma Decoding MDS Codes.

\section{ANALISIS PERFORMANSI}

Parameter yang digunakan untuk menganalisis performansi meliputi PLR dan throughput.

\subsection{Packet-Loss-Rate (PLR)}

Packet-Loss-Rate adalah rasio perbandingan antara paket yang loss dengan paket yang dikirimkan. Skema decoding untuk performansi PLR dievaluasi menggunakan simulasi komputer untuk $N_{h}=200$ slot dan $N_{m}=180$ slot. Ada dua kondisi yang dibandingkan dalam simulasi yaitu kondisi pada saat belum terjadi fading dan kondisi setelah adanya frequency- 
flar Rayleigh fading. Dari hasil simulasi yang diperoleh PLR manusia lebih baik dibandingkan dengan PLR mesin. PLR dari $10^{-1}$, saat kondisi tanpa fading manusia memiliki nilai $G_{h}=0.33$ paket/slot dan setelah terkena fading memiliki nilai $G_{h}=0.3$ paket/slot, sedangkan kondisi tanpa fading mesin memiliki nilai $G_{m}=0.31$ paket/slot dan setelah terkena fading memiliki nilai $G_{m}=0.13$ paket $/$ slot. Total jumlah offered traffic manusia dan mesin $\left(G=G_{h}+G_{m}\right)=$ 0.61 paket/slot untuk kondisi tanpa fading dan jumlah offered traffic manusia dan mesin $(G=$ $\left.G_{h}+G_{m}\right)=0.43$ paket/slot untuk kondisi setelah adanya fading. Penurunan nilai offered traffic karena fading terjadi karena adanya fluktuasi sinyal akibat adanya sinyal multipath yang terdistribusi.

\subsection{Throughput}

Analisis throughput diperlukan terutama ketika PLR memiliki nilai error floor (lonjakan) yang tidak terhingga. Throughput adalah rasio jumlah paket yang diterima benar dengan jumlah total paket yang dikirimkan. Berdasarkan nilai PLR seperti pada Gambar 5, thoughput dalam jaringan dapat dihitung menggunakan Persamaan (20):

$$
\begin{aligned}
& T_{h}=G_{h} *\left(1-P_{L}^{h}\right), \\
& T_{m}=G_{m} *\left(1-P_{L}^{m}\right)
\end{aligned}
$$

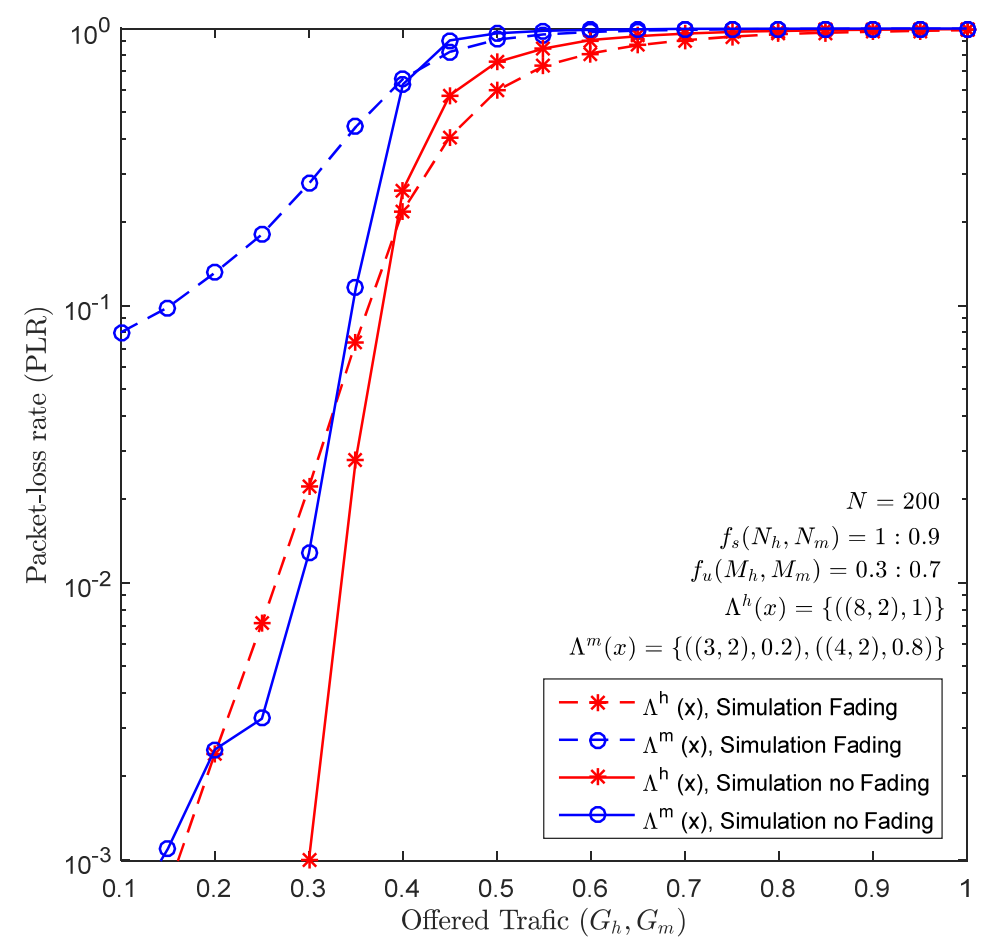

Gambar 5. PLR untuk Manusia dan Mesin dengan $N=200$. 


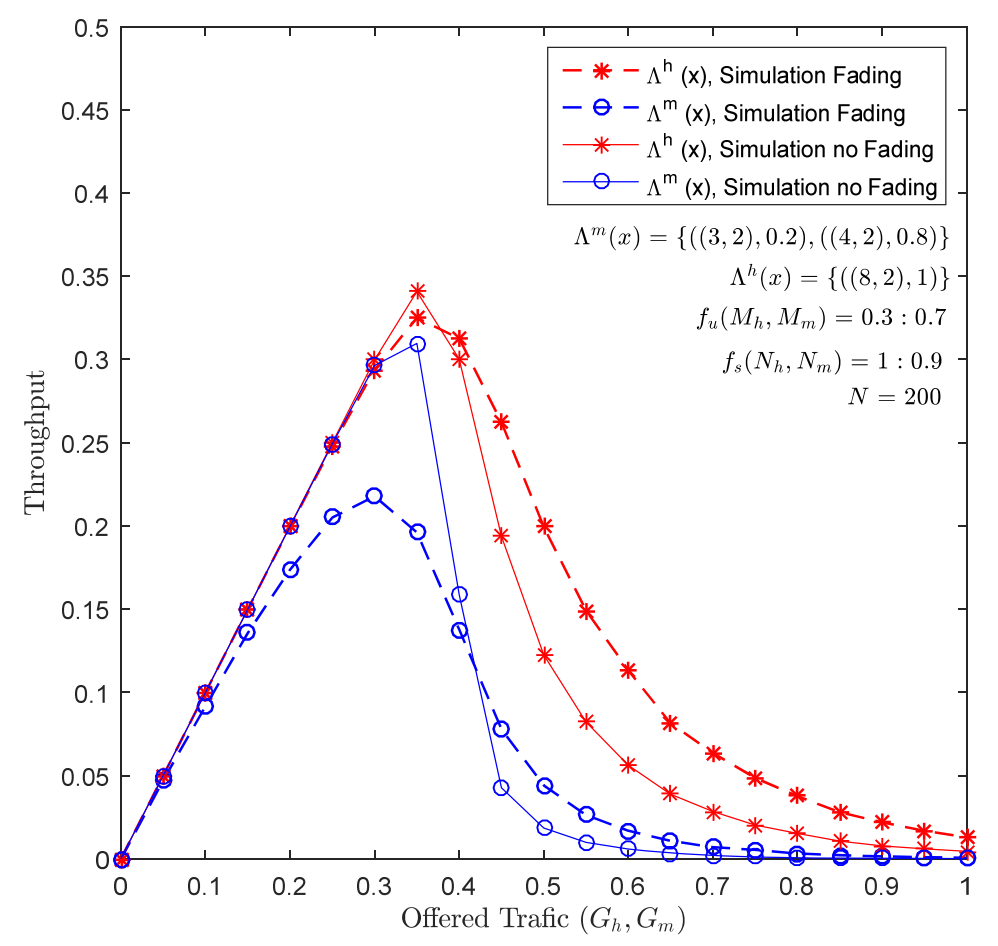

Gambar 6. Throughput untuk Manusia dan Mesin dengan $N=200$.

PLR untuk manusia dan mesin dinotasikan $P_{L}^{h}$ dan $P_{L}^{m}$. Gambar 6 merupakan nilai performansi throughput untuk manusia dan mesin sesuai dengan usulan degree distribution pada Persamaan (15). Sebelum adanya fading grup manusia memiliki nilai throughput sebesar $T_{h}=0.35$ paket/slot dan setelah adanya fading grup manusia memiliki nilai throughputsebesar $T_{h}=0.34$ paket/slot, sedangkan nilai throughput grup mesin sebelum ada fading sebesar $T_{m}=0.32$ paket/slot dan setelah fading nilai throughput grup mesin sebesar $T_{m}=0.22$ paket/slot.

Berdasarkan hasil proyeksi EXIT Chart, performansi PLR dan throughput, grup manusia memiliki performansi yang lebih bagus daripada grup mesin. Sehingga dapat disimpulkan bahwa sub optimal degree distribution yang diusulkan sudah dapat memprioritaskan manusia dari pada mesin dalam jaringan super padat dimasa depan.

\section{KESIMPULAN}

Usulan CRA dengan memprioritaskan manusia daripada mesin menggunakan MDS Codes untuk jaringan super padat pada masa depan. Degree distribution untuk grup manusia dan mesin menggunakan utility function dimana proses optimasi menggunakan proyeksi EXIT Chart dengan binary erasure channel (BEC). Sub-optimal degree distribusi yang diusulkan $\Lambda^{h}(x)=\{((8,2), 1)\}$ dan $\left.\Lambda^{m}(x)=\{((3,2), 0.2),((4,2), 0.8))\right\}$ dengan nilai throughput sebelum adanya fading grup manusia memiliki nilai sebesar $T_{h}=0.35$ paket/slot dan setelah adanya fading throughput manusia sebesar $T_{h}=0.34$ paket/slot, sedangkan nilai throughput grup mesin sebelum ada fading sebesar $T_{m}=0.32$ paket/slot dan setelah fading nilai throughput mesin sebesar $T_{m}=0.22$ paket/slot. Penelitian ini juga mengevaluasi performansi dari CRA 
dengan prioritas menggunakan frequency-flat Rayleigh fading channel, dimana hasilnya juga menunjukkan manusia masih dapat diprioritaskan meskipun dalam kondisi terkena fading. Grup manusia lebih diprioritaskan daripada mesin dilihat dari nilai PLR dan throughput yang tinggi dibandingkan grup mesin. Utility function digunakan sebagai ukuran dari suatu jaringan. Performansi yang bagus dari usulan prioritas manusia dibandingkan mesin dengan menggunakan MDS Codes memiliki kontribusi yang signifikan terhadap jaringan super padat dimasa depan khususnya pada era $5 \mathrm{G}$.

\section{UCAPAN TERIMA KASIH}

Penulis mengucapkan terima kasih khususnya kepada Bapak Dr. Eng Khoirul Anwar, S.T., M.Eng yang telah memberikan bimbingan dan ide-idenya yang luar biasa kepada penulis sehingga penulis dapat menyelesaikan jurnal ini. Terima Kasih juga penulis ucapkan kepada Lembaga Penelitian dan Pengabdian Masyarakat (LPPM) Institut Teknologi Telkom Purwokerto atas bantuan dan dukungannya.

\section{DAFTAR RUJUKAN}

Anwar, K. (2016). High-dense Multiway Relay Networks Exploiting Direct Links as side Information. IEEE International Conference on Communications (ICC). Kuala Lumpur, Malaysia, (pp. 1-6).

Anwar, K., \& Matsumoto, T. (2012). Accumulator-Assisted Distributed Turbo Codes for Relay Systems Exploiting Source-Relay Correlation. Journal IEEE Communications Letters. 16(7), $1114-1117$.

Anwar, K. (2016). Decoding for Wireless Super-dense networks and its Finite-length Analysis for Practical Applications). International Symposium on Electronics and Smart Devices (ISESD). Bandung, Indonesia.

Chung, S.-Y., Forney, G.D., Jr, F., Richardson, T.J., \& Urbanke, R. (2011). On the Design of Low-density Parity-check Codes within $0.0045 \mathrm{db}$ of the Shannon Limit. Journal IEEE Communications Letters. 5(2), 58-60.

Ericsson. (2011). More than 50 billion connected devices. Ericsson Whitepaper, (pp. 1-12).

Hasan, M.N., \& Anwar, K. (2015). Massive Uncoordinated Multiway Relay Networks with Simultaneous Detections. IEEE International Conf. on Comm. Workshop (ICCW). London, (pp. 2175-2180).

Hasan, M.N., \& Anwar, K. (2015). Uncoordinated Transmissions in Multi-way relaying Systems. ITG Conference on Systems, Communications and Coding (SCC). Hamburg, Germany, (pp. 1-5).

Larasati, S., Ramatryana, I.N.A., \& Anwar, K. (2018). High-rate Coded Random Access for Non-Orthogonal Multiple Access with Human Priority. $2^{\text {nd }}$ International Conference on Telematics and Future Generation Networks (TAFGEN). Kuching, Malaysia. 
Purwita, A.A., \& Anwar, K. (2016). Massive Multiway Relay Networks Applying Coded Random Access. Journal IEEE Transaction on Communications. 64(10), 1-12.

Toni, L., \& Frossard, P. (2015). Prioritized Random mac Optimization Via Graphbased Analysis. Journal IEEE Transaction on Communications. 63(12), 1-12.

Woo, S.S., \& Cheng, M.K. (2008). Prioritized LT codes. Conference on Information Sciences and Systems (CISS). Princenton, United States of America. 